\title{
C3aR and C5aR1 act as key regulators of human and mouse $\beta$-cell function
}

\author{
Patricio Atanes $^{1}$ (D) Inmaculada Ruz-Maldonado ${ }^{1} \cdot$ Attilio Pingitore $^{1} \cdot$ Ross Hawkes $^{1} \cdot$ \\ Bo Liu ${ }^{1} \cdot$ Min Zhao $^{1} \cdot$ Guo Cai Huang $^{1} \cdot$ Shanta J. Persaud $^{1} \cdot$ Stefan Amisten $^{1}$
}

Received: 22 June 2017 / Revised: 22 August 2017 / Accepted: 6 September 2017 / Published online: 18 September 2017

(C) The Author(s) 2017. This article is an open access publication

\begin{abstract}
Aims Complement components 3 and 5 (C3 and C5) play essential roles in the complement system, generating $\mathrm{C} 3 \mathrm{a}$ and C5a peptides that are best known as chemotactic and inflammatory factors. In this study we characterised islet expression of $\mathrm{C} 3$ and $\mathrm{C} 5$ complement components, and the impact of $\mathrm{C} 3 \mathrm{aR}$ and $\mathrm{C} 5 \mathrm{aR} 1$ activation on islet function and viability.

Materials and methods Human and mouse islet mRNAs encoding key elements of the complement system were quantified by qPCR and distribution of $\mathrm{C} 3$ and $\mathrm{C} 5$ proteins was determined by immunohistochemistry. Activation of $\mathrm{C} 3 \mathrm{aR}$ and C5aR1 was determined using DiscoverX betaarrestin assays. Insulin secretion from human and mouse islets was measured by radioimmunoassay, and intracellular calcium $\left(\left[\mathrm{Ca}^{2+}\right] \mathrm{i}\right)$, ATP generation and apoptosis were assessed by standard techniques.

Results $\mathrm{C} 3$ and $\mathrm{C} 5$ proteins and $\mathrm{C} 3 \mathrm{aR}$ and $\mathrm{C} 5 \mathrm{aR} 1$ were expressed by human and mouse islets, and $\mathrm{C} 3$ and $\mathrm{C} 5$ were mainly localised to $\beta$ - and $\alpha$-cells. Conditioned media from islets exposed for $1 \mathrm{~h}$ to 5.5 and $20 \mathrm{mM}$ glucose stimulated
\end{abstract}

S.J. Persaud and S. Amisten contributed equally to this work.

Electronic supplementary material The online version of this article (doi:10.1007/s00018-017-2655-1) contains supplementary material, which is available to authorized users.

Patricio Atanes

patricio.atanes_juiz@kcl.ac.uk

Shanta J. Persaud

shanta.persaud@kcl.ac.uk

1 Diabetes Research Group, Division of Diabetes and Nutritional Sciences, Faculty of Life Sciences and Medicine, Hodgkin Building, King's College London, Guy's Campus, London SE1 1UL, UK
C3aR and C5aR1-driven beta-arrestin recruitment. Activation of $\mathrm{C} 3 \mathrm{aR}$ and $\mathrm{C} 5 \mathrm{aR} 1$ potentiated glucose-induced insulin secretion from human and mouse islets, increased $\left[\mathrm{Ca}^{2+}\right] \mathrm{i}$ and ATP generation, and protected islets against apoptosis induced by a pro-apoptotic cytokine cocktail or palmitate. Conclusions Our observations demonstrate a functional link between activation of components of the innate immune system and improved $\beta$-cell function, suggesting that lowlevel chronic inflammation may improve glucose homeostasis through direct effects on $\beta$-cells.

Keywords G protein-coupled receptors - Islets of Langerhans $\cdot$ Insulin secretion $\cdot$ Alternative complement pathway $\cdot \mathrm{C} 3 \mathrm{aR} \cdot \mathrm{C} 5 \mathrm{aR} 1$

\section{Introduction}

Type 2 diabetes (T2D) is a chronic disease characterised by increased insulin resistance and decreased $\beta$-cell mass and function [1]. The complement system, an important component of the innate immune system, consists of several small, inactive serum precursor proteins that are mainly synthesised by the liver. Upon activation, proteases cleave the precursor $\mathrm{C} 3$ and $\mathrm{C} 5$ into the active complement fragments $\mathrm{C} 3 \mathrm{a}$, $\mathrm{C} 3 \mathrm{~b}, \mathrm{C} 5 \mathrm{a}$ and $\mathrm{C} 5 \mathrm{~b}$. These proteolytic cleavage cascades of intact $\mathrm{C} 3$ and $\mathrm{C} 5$ are responsible for the formation of a membrane attack complex and activation of an adaptive immune response [2]. The $\mathrm{C} 3 \mathrm{a}$ and $\mathrm{C} 5 \mathrm{a}$ peptide fragments that are generated, also known as anaphylatoxins, are responsible for production of local inflammatory responses and they exert at least part of their biological effects via activating the $\mathrm{G}$ protein-coupled receptors (GPCRs) $\mathrm{C} 3 \mathrm{aR}, \mathrm{C} 5 \mathrm{aR} 1$ and $\mathrm{C} 5 \mathrm{aR} 2$ that are encoded by the C3AR1, C5AR1 and C5AR2 genes [3-5]. 
In addition to their roles in innate immunity, an emerging body of literature suggests that intact $\mathrm{C} 3$ and $\mathrm{C} 5$ complement proteins, and the cleaved $\mathrm{C} 3 \mathrm{a}$ and $\mathrm{C} 5 \mathrm{a}$ peptides, are important in regulating whole body metabolism, energy homeostasis and the pathogenesis of diabetes and metabolic syndrome. For example, C3/C3a are positively associated with the incidence of diabetes [6-8] and insulin resistance $[9,10]$, and C5/C5a contribute to adipose tissue inflammation and insulin resistance [11, 12]. Moreover, C3a and C5a receptor antagonists have been reported to inhibit dietinduced obesity, metabolic dysfunction, and adipocyte and macrophage signalling in vivo in the rat [13]. In contrast, the adipokine adipsin (also known as complement factor D (CFD)), an adipose tissue-derived protease required for the generation of the $\mathrm{C} 3$ convertase, improves islet $\beta$-cell function by increasing conversion of circulating $\mathrm{C} 3$ into $\mathrm{C} 3 \mathrm{a}$ [14]. Thus, studies to date implicate intact $\mathrm{C} 3$ and $\mathrm{C} 5$ and their peptide fragments in metabolic dysregulation through induction of insulin resistance, while a report with adipsin [14] suggests beneficial effects of C3a on $\beta$-cells. Since very little is currently known about the direct effects of $\mathrm{C} 3 / \mathrm{C} 3 \mathrm{a}$ and C5/C5a on $\beta$-cell function, the aims of this study were to determine the mRNA and protein expression of $\mathrm{C} 3 / \mathrm{C} 3 \mathrm{a}$ and C5/C5a in islets, and identify the effects of C3aR and C5aR1 activation on human and mouse islet secretory function and viability.

\section{Materials and methods}

\section{Reagents}

The C3aR agonist sc-214644, C3aR antagonist SB 290157 and C5aR1 agonist 65121-ANA were from Cambridge Bioscience (Cambridge, UK). The C5aR1 antagonists PMX 205 and W 54011 were from Tocris Bioscience (Bristol, UK). Intact C3 and C5 proteins were from Millipore (UK) Limited (Hertfordshire, UK), C3 antibody was from LifeSpan BioSciences, Inc. (Seattle, USA) and C5 antibody was from Insight Biotechnology (Wembley, UK). The glucagon antibody was from Sigma-Aldrich (Dorset, UK), insulin antibody from DAKO UK Ltd. (Ely, UK) and somatostatin antibody from Abcam plc (Cambridge, UK). Anti-rabbit, anti-guinea pig, anti-rat and anti-mouse secondary antibodies were from Jackson ImmunoResearch (Suffolk, UK). DAPI nucleic acid stain was from Thermo Fisher Scientific (Northumberland, UK). C3aR and C5aR1 beta-arrestin assays were from DiscoverX Corporation, Ltd. (Birmingham, UK). Recombinant murine TNF $\alpha$, IFN $\gamma$ and IL-1 $\beta$ were from PeproTech EC Ltd. (London, UK). Caspase 3/7 assay kits and CellTiter-Glo ${ }^{\circledR}$ 3D assay kits were from Promega UK (Southampton, UK). The TaqMan RT-PCR kit was from Thermo Fisher Scientific (Loughborough, UK) and QuantiTect SYBR Green qPCR kits with QuantiTect qPCR assays were from Qiagen Ltd. (Manchester, UK). All other chemicals were from Sigma-Aldrich or Thermo Fisher Scientific.

\section{Human and mouse islet isolation and culture}

Islets were isolated from 10-12-week-old male Crl:CD1 (ICR) mice (Charles River), by collagenase digestion of the exocrine pancreas [15]. Human islets were isolated from heart-beating non-diabetic donors, with appropriate ethical approval, at the King's College London Human Islet Isolation Unit [16]. Islets were maintained overnight at $37{ }^{\circ} \mathrm{C}$ in culture medium supplemented with $5.6 \mathrm{mM}$ glucose, $10 \%$ FCS, $2 \mathrm{mM}$ glutamine and penicillin-streptomycin (100 U/ $\mathrm{mL}, 0.1 \mathrm{mg} / \mathrm{mL}$ ) before experimental use.

\section{RNA extraction and quantitative real-time PCR}

A modified TRIzol protocol [17] was used to extract total RNA from human and mouse islets, and RNA was converted into cDNA using the TaqMan RT-PCR kit. Real-time PCR was performed using a LightCycler480 and gene expression relative to the house-keeping genes ACTB, GAPDH, PPIA, TBP and TCRF was carried out using QuantiTect qPCR assays (Supplementary Table 1), as described elsewhere $[18,19]$. All complement and reference gene primer efficiency (E) [20] values were in the range of 1.85-2.15. For all complement and reference gene quantifications, template cDNAs were diluted in such a way that all quantified genes returned $C_{\mathrm{t}}$ values $<30$. Genes that expressed $<0.001 \%$ of the mean level of the house keeping genes were considered to be present only at trace level, as their mRNA expression was below the lower limit of linear quantification for the QuantiTect primer assays.

\section{Immunohistochemistry}

$\mathrm{C} 3$ and C5 complement protein expression by mouse and human pancreas was determined using rabbit anti-C3 and anti-C5 antibodies (both at 1:20) and Alexa Fluor ${ }^{\circledR} 488$ anti-rabbit secondary antibody (1:150). C3 and C5 protein localisation in islet cells was probed by co-staining with guinea pig anti-insulin (1:200), mouse anti-glucagon (1:100) and rat anti-somatostatin (1:50) and species-specific Alexa Fluor ${ }^{\circledR} 594$ secondary antibodies (all at 1:200). Nuclei were detected using DAPI (1:500). Specificity of immunofluorescent staining was confirmed by staining consecutive sections in the absence of primary antibody but with secondary antibody alone (at 1:150). 


\section{Beta-arrestin assays}

Induction of beta-arrestin recruitment for $\mathrm{C} 3 \mathrm{aR}$ and $\mathrm{C} 5 \mathrm{aR} 1$ was determined using PathHunter ${ }^{\circledR}$ eXpress C3aR U2OS and C5aR1 CHO-K1 GPCR beta-arrestin kits. In brief, 8000 $\mathrm{C} 3 \mathrm{aR}$ U2OS or C5aR1 CHO-K1 cells were dispensed into wells of the 96-well plate and incubated for $48 \mathrm{~h}\left(37^{\circ} \mathrm{C}, 5 \%\right.$ $\mathrm{CO}_{2}$ ). These cells were then exposed for $90 \mathrm{~min}$ to $\mathrm{C} 3 \mathrm{aR}$ and $\mathrm{C} 5 \mathrm{aR} 1$ agonists, intact $\mathrm{C} 3$ or $\mathrm{C} 5$ complement proteins or conditioned medium obtained from mouse islets that had been incubated for $1 \mathrm{~h}\left(37^{\circ} \mathrm{C}, 5 \% \mathrm{CO}_{2}\right)$ in a physiological salt solution in the absence of glucose or in medium supplemented with 5.5 or $20 \mathrm{mM}$ glucose. Beta-arrestin activity driven by $\mathrm{C} 3 \mathrm{aR}$ and $\mathrm{C} 5 \mathrm{aR} 1$ was quantified according to the manufacturer's instructions using a luminescence plate reader on an unfiltered, full-range luminescence setting.

\section{Static insulin secretion}

Groups of five mouse and human islets were incubated for $1 \mathrm{~h}$ in a physiological salt solution [21], either in the absence or presence of $1 \mu \mathrm{M} \mathrm{C} 3 \mathrm{aR}$ or $\mathrm{C} 5 \mathrm{aR} 1$ agonists or antagonists or with $100 \mathrm{nM}$ intact $\mathrm{C} 3$ or $\mathrm{C} 5$ complement proteins (alone or in combination with $1 \mu \mathrm{M}$ of the respective antagonist). In some experiments insulin secretion was quantified in the presence of increasing concentrations $(1 \mathrm{nM}-10 \mu \mathrm{M})$ of C3aR or C5aR1 antagonists SB 290157, PMX 205 or W 54011. Insulin secreted into the supernatant was quantified by radioimmunoassay, essentially as described elsewhere [22].

\section{Dynamic insulin secretion}

The effects of agonists and antagonists at $\mathrm{C} 3 \mathrm{aR}$ or $\mathrm{C} 5 \mathrm{aR} 1$ on dynamic insulin secretion from human islets were assessed using a temperature-controlled perifusion system [23, 24]. Briefly, 50 human islets were transferred to chambers containing $1 \mu \mathrm{m}$ filters and perifused $\left(37{ }^{\circ} \mathrm{C}, 0.5 \mathrm{~mL} / \mathrm{min}\right)$ with a salt solution [21] containing 2 or $20 \mathrm{mM}$ glucose in the absence or presence of $\mathrm{C} 3 \mathrm{aR}$ or $\mathrm{C} 5 \mathrm{aR} 1$ agonists and/ or antagonists. Perifusate samples were collected at 2-min intervals and secreted insulin was quantified by radioimmunoassay [22].

\section{ATP}

Islet ATP production, which is a marker of islet metabolism, was quantified using the CellTiter-Glo ${ }^{\circledR}$ 3D assay. 200 mouse islets were pre-incubated for $1 \mathrm{~h}$ in a salt solution [21] supplemented with $2 \mathrm{mM}$ glucose then groups of 3 islets were incubated in 96-well plates in the absence or presence of intact $\mathrm{C} 3$ or $\mathrm{C} 5$ complement proteins or $\mathrm{C} 3 \mathrm{aR}$ or $\mathrm{C} 5 \mathrm{aR} 1$ agonists or antagonists. Cells were lysed and ATP was quantified according to the manufacturer's instructions.

\section{Intracellular calcium $\left(\left[\mathrm{Ca}^{2+}\right] \mathbf{i}\right)$}

Groups of approximately 100,000 dispersed mouse islet cells were seeded onto glass coverslips, maintained in culture overnight then loaded with $5 \mu \mathrm{M}$ Fura-2 AM for $30 \mathrm{~min}$. Cells were perifused $\left(37^{\circ} \mathrm{C}, 1 \mathrm{~mL} / \mathrm{min}\right)$ with a physiological salt solution in the absence or presence of test agents and real-time changes in $\left[\mathrm{Ca}^{2+}\right]$ i were determined by illuminating cells alternately at 340 and $380 \mathrm{~nm}$, with emitted light being filtered at $510 \mathrm{~nm}$.

\section{Apoptosis}

Mouse and human islet apoptosis was assessed in the presence or absence of C3aR or C5aR1 agonists and/or antagonists using the Caspase-Glo 3/7 assay according to the manufacturer's instructions. Anti-apoptotic effects were evaluated following induction of apoptosis by either palmitate $(500 \mu \mathrm{M})$ or a cocktail of pro-apoptotic cytokines (25 U/ $\mathrm{mL}$ IL-1 $\beta ; 1000 \mathrm{U} / \mathrm{mL}$ TNF $\alpha ; 1000 \mathrm{U} / \mathrm{mL}$ IFN $\gamma$ ).

\section{Statistical analysis}

GraphPad Prism 5.0 (GraphPad Software, Inc) was used for statistical analysis. Data are presented as mean \pm SEM and were analysed using ANalysis Of VAriance (ANOVA). Statistical significance was set at $p$ values of $<0.05(*),<0.01$ $(* *),<0.001(* * *),<0.0001(* * * *)$.

\section{Results}

\section{Quantification of complement component mRNA expression in human and mouse islets}

Human and mouse islets expressed similar levels of mRNAs encoding intact $\mathrm{C} 3$ and $\mathrm{C} 5$ complement proteins, with $\mathrm{C} 3$ mRNA levels being approximately 20 -fold higher than those of C5 (Fig. 1). The qPCR analysis also indicated that human and mouse islets expressed mRNAs encoding the receptors through which active $\mathrm{C} 3 \mathrm{a}$ and $\mathrm{C} 5 \mathrm{a}$ complement peptides exert their effects. Thus, C3aR mRNA was expressed at high levels in mouse islets and at low levels in human islets, whereas mRNA encoding C5aR1 was found at intermediate or low levels in human and mouse islets, respectively. C5a is also a ligand for C5aR2, but mRNA encoding this receptor was below the lower limit of linear quantification for the QuantiTect primer assays in both human and mouse islets. Complement factor D (CFD), also known as adipsin, and 


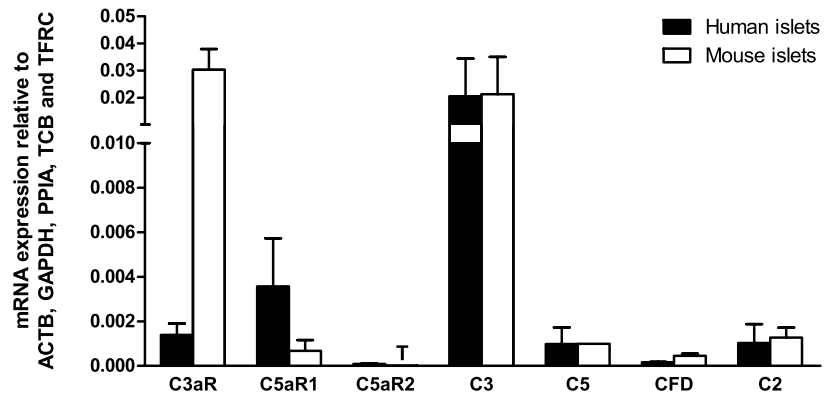

Fig. 1 Relative mRNA expression of complement receptors and proteins by human and mouse islets. Data are presented as mean expression relative to the reference genes ACTB, GAPDH, PPIA, TBP and TFRC. $T$ trace mRNA expression, $C 3 a R$ complement receptor $\mathrm{C} 3 \mathrm{a}$, C5aR1 complement receptor C5a1, C5aR2 complement receptor C5a2, C3 complement component 3, C5 complement component 5, $C F D$ complement factor D (adipsin), $C 2$ complement component 2 , $n=3-4$ individual human or mouse islet donors

complement 2 (C2) help encoding complement cascade proteins with $\mathrm{C} 3$ and $\mathrm{C} 5$ convertase activity [25], which cleave $\mathrm{C} 3$ and $\mathrm{C} 5$ to generate the active $\mathrm{C} 3 \mathrm{a}$ and $\mathrm{C} 5 \mathrm{a}$ peptides. Both CFD and $\mathrm{C} 2$ mRNAs were detectable at low levels in human and mouse islets (Fig. 1).

\section{Immunohistochemical detection of $\mathrm{C} 3$ and $\mathrm{C} 5$ in mouse and human pancreas}

Fluorescence immunohistochemical staining indicated that C3 was distributed throughout mouse (Fig. 2A) and human (Fig. 2B) islets. Co-staining with antibodies against insulin, glucagon and somatostatin demonstrated that $\mathrm{C} 3$ co-localised with all three hormones, indicating that it is expressed by $\alpha$-, $\beta$ - and $\delta$-cells (Fig. 2a, b, e, g). C5 was also detected in mouse (Fig. 2c) and human (Fig. 2d) islets, where it colocalised primarily with insulin, and low expression of this complement protein was also detected in $\alpha$ - and $\delta$-cells (Fig. 2c, d, f, h). C3 and C5 proteins were also expressed by exocrine cells in both mouse and human pancreas (Fig. 2a-d).

\section{Quantification of C3aR and C5aR1 activation}

DiscoverX beta-arrestin reporter cell assays indicated that commercially available selective agonists for $\mathrm{C} 3 \mathrm{aR}$ (sc-214644) and C5aR1 (65121-ANA) induced concentration-dependent activation of $\mathrm{C} 3 \mathrm{aR}$ and $\mathrm{C} 5 \mathrm{aR} 1$, with half-maximal activation at $804 \mathrm{nM} \mathrm{sc}-214644$ and $292 \mathrm{nM}$ 65121-ANA, respectively (Fig. 3a, b). The agonists were, therefore, used at $1 \mu \mathrm{M}$ for islet functional experiments to ensure robust activation of $\mathrm{C} 3 \mathrm{aR}$ and $\mathrm{C} 5 \mathrm{aR} 1$. Intact $\mathrm{C} 3$ and C5 complement proteins also stimulated C3aR- and C5aR1dependent beta-arrestin recruitment: $\mathrm{C} 3$ activated $\mathrm{C} 3 \mathrm{aR}$ and, to a much lesser extent, C5aR1, whereas C5 only evoked beta-arrestin recruitment to C5aR1 (Fig. 3c, d).

\section{Islet-derived C3aR and C5aR1-activating factors}

Since our qPCR and immunohistochemical data indicated that islets express intact $\mathrm{C} 3$ and $\mathrm{C} 5$, the beta-arrestin assays were also used to determine whether factors capable of activating $\mathrm{C} 3 \mathrm{aR}$ and $\mathrm{C} 5 \mathrm{aR} 1$ were released from islets. Conditioned media retrieved from mouse islets that had been incubated for $1 \mathrm{~h}$ stimulated C3aR (Fig. 4a) and C5aR 1 (Fig. 4b) beta-arrestin recruitment in a glucose concentration-dependent manner, while medium from islets that had been incubated in the absence of glucose did not activate the receptors.

\section{Effects of modifying C3aR and C5aR1 activity on glucose-induced insulin secretion}

Exposure of mouse and human islets to C3aR $(1 \mu \mathrm{M}$, sc-214644) and C5aR1 (1 $\mu \mathrm{M}, 65121$-ANA) agonists resulted in significant potentiation of glucose-induced insulin secretion, and stimulatory effects were also observed when islets were incubated with intact $\mathrm{C} 3$ and $\mathrm{C} 5$ (Fig. 5a-d). Potentiation of insulin secretion by intact $\mathrm{C} 3$ and $\mathrm{C} 5$ was reduced by co-incubation of islets with $\mathrm{C} 3 \mathrm{aR}$ and C5aR1 antagonists, which also inhibited insulin secretion stimulated by $20 \mathrm{mM}$ glucose alone (Fig. 5a-d). This inhibition of glucose-stimulated insulin secretion by $\mathrm{C} 3 \mathrm{aR}$ and C5aR1 antagonists was confirmed by constructing concentration-response curves using mouse islets, which indicated half-maximal inhibition at $\sim 45-80 \mathrm{nM}$ of antagonists and maximal inhibition at $1 \mu \mathrm{M}$ (Supplementary Figure 1A-C). Based on these results, antagonists were used in functional experiments at $1 \mu \mathrm{M}$ to maximally inhibit $\mathrm{C} 3 \mathrm{aR}$ and $\mathrm{C} 5 \mathrm{aR} 1$. Time-resolved perifusion experiments with human islets confirmed the capacity of sc-214644 (Fig. 6a) and 65121ANA (Fig. 6b) to potentiate glucose-induced insulin secretion. The elevation in insulin release with both agonists was rapid in onset and insulin secretion was significantly reduced in the presence of SB 290157 and PMX 205.

\section{Effects of modifying C3aR and C5aR1 activity on islet ATP generation}

Quantification of islet ATP generation indicated that C3aR activation with $1 \mu \mathrm{M} \mathrm{sc}-214644$ significantly elevated ATP generation at $20 \mathrm{mM}$ glucose, and similar effects were obtained following C5aR 1 activation by $1 \mu \mathrm{M}$ 65121-ANA (Fig. 7). Exposure of mouse islets to $100 \mathrm{nM}$ intact C3 or C5 also significantly potentiated glucose-stimulated ATP production while $\mathrm{C} 3 \mathrm{aR}$ and $\mathrm{C} 5 \mathrm{aR} 1$ antagonists significantly inhibited ATP generation at $20 \mathrm{mM}$ glucose (Fig. 7). 
Fig. 2 Expression of $\mathrm{C} 3$ and C5 complement proteins by mouse and human pancreas. A-D Co-localisation of C3 $(\mathbf{A}, \mathbf{B})$ and C5 (C, D) complement proteins (green) with the islet hormones insulin $(a-c)$, glucagon $(d-f)$ and somatostatin $(g-i)($ red) in mouse $(\mathbf{A}, \mathbf{C})$ and human $(\mathbf{B}, \mathbf{D})$ islets. Nuclei have been counterstained with DAPI (blue). C3 and C5 were also expressed by exocrine cells in both mouse and human pancreas. E, G C3 co-localises in mouse and human islets with insulin, glucagon and somatostatin, indicating expression of $\mathrm{C} 3$ in $\beta$-, $\alpha$ - and $\delta$-cells. $\mathbf{F}, \mathbf{H}$ C5 co-localises in mouse and human islets primarily with insulin, indicating predominant expression of $\mathrm{C} 5$ in $\beta$-cells
(A)
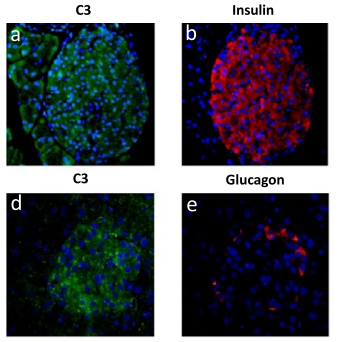

c3
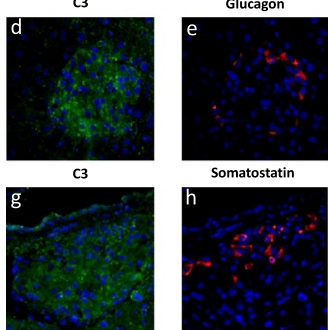

Somatostatin

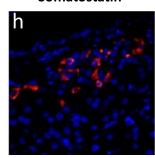

(C)
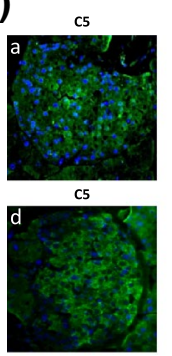

c5
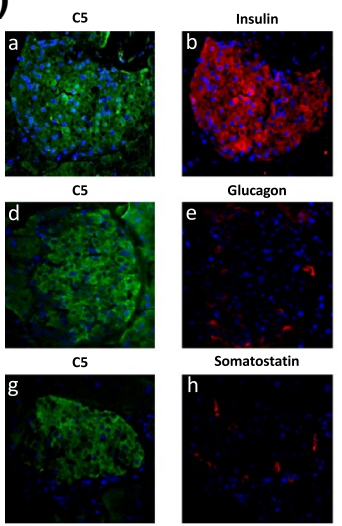

Glucagon

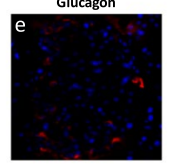

Somatostatin
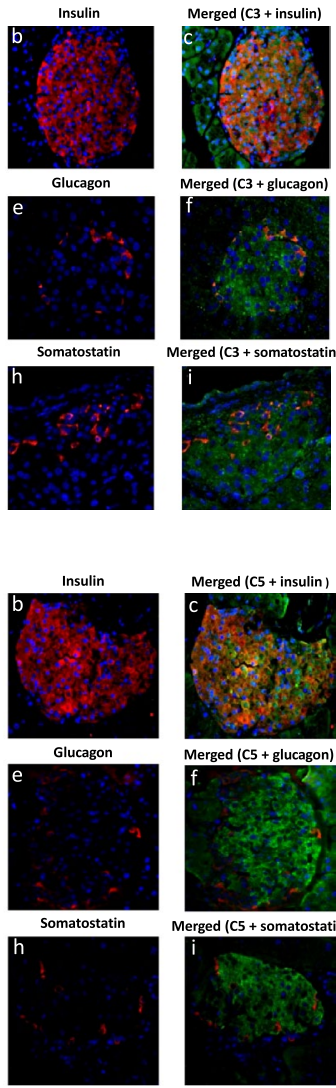

Merged (C3 + glucagon)

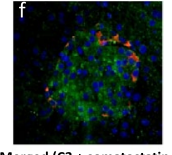

Merged (C3 + somatostatin)

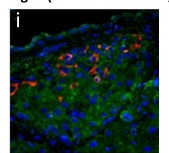

(B)
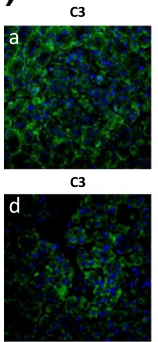

C3
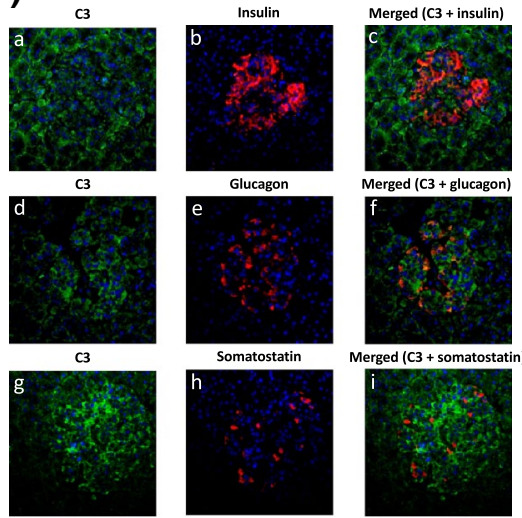

Glucagon

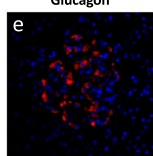

Merged (C3 + glucagon)

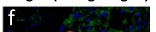

Somatostatin

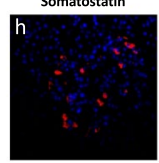

Mer

Merged (C3 + somatostatin)

(D)

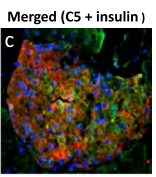

Merged (C5 + glucagon)

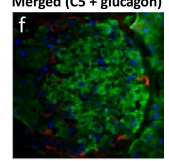

Merged (C5 + somatostatin)
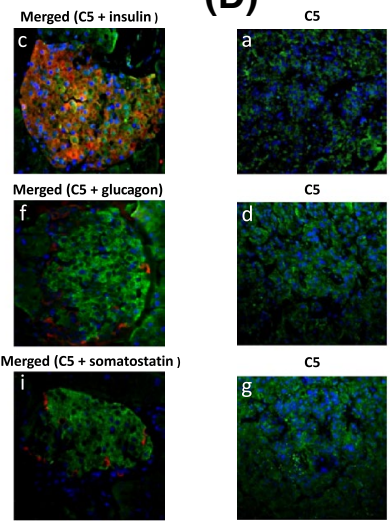

C5

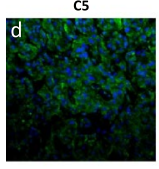

C5

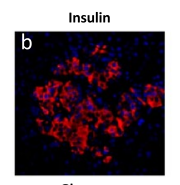

Merged (C5 + insulin)

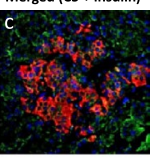

Glucagon

Merged (C5 + glucagon)
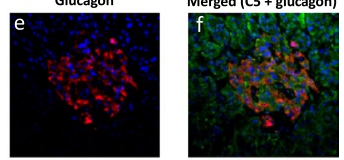

Somatostatin

Merged (C5 + somatostatin)
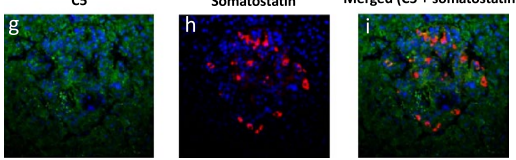

(E)

Mouse islet cells

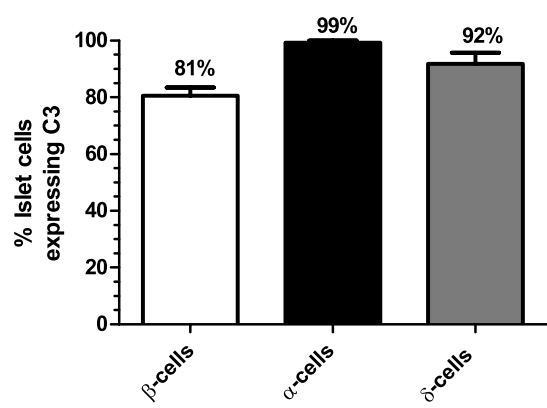

(G)

Human islet cells

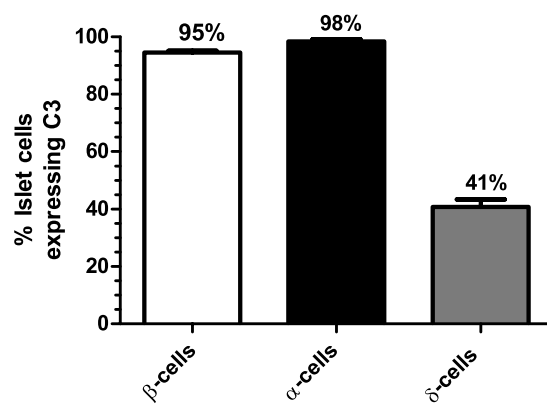

(F)

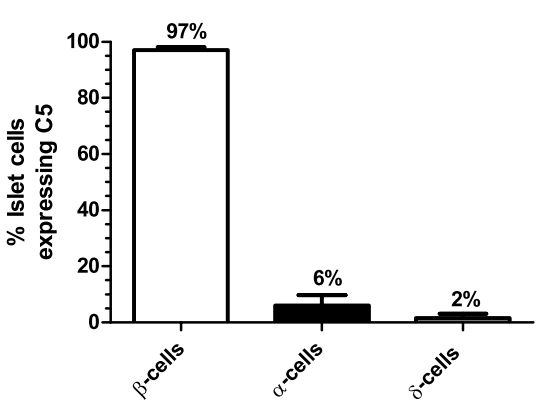

(H)

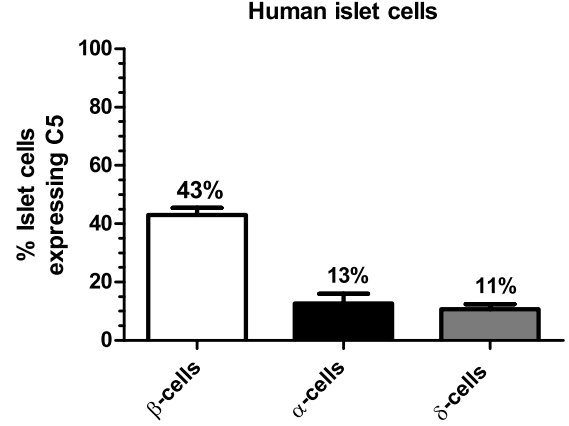


Fig. $3 \mathrm{C} 3 \mathrm{aR}$ and C5aR1 betaarrestin recruitment. a, b Concentration-response curves for high affinity C3aR (sc-214644) and C5aR1 (65121-ANA)

agonists. c Intact C3 (solid line) induced concentration-dependent activation of $\mathrm{C} 3 \mathrm{aR}$, whereas intact C5 (dotted line) had no effect. d Intact C5 induced concentration-dependent activation of C5aR1 (dotted line), and very weak activation was also observed with intact C3 (solid line)
(A)

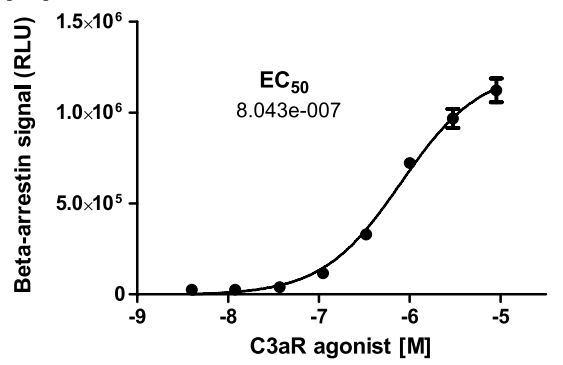

(C)

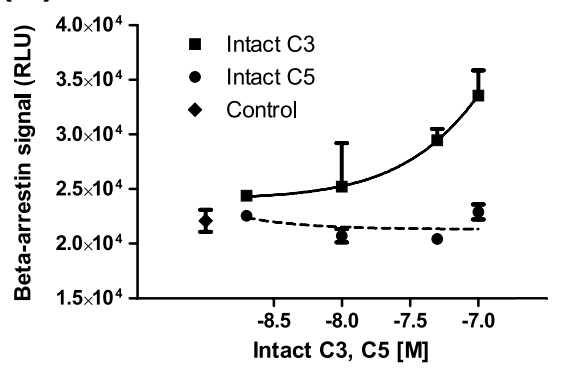

(B)

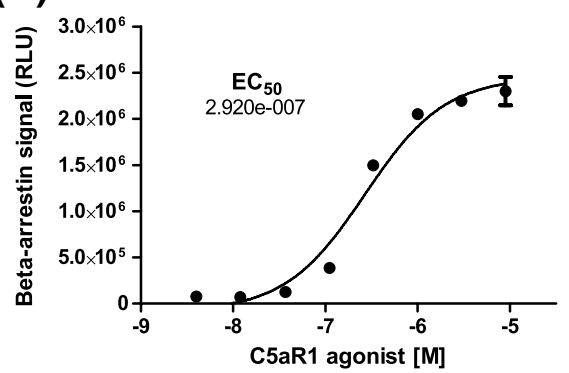

(D)

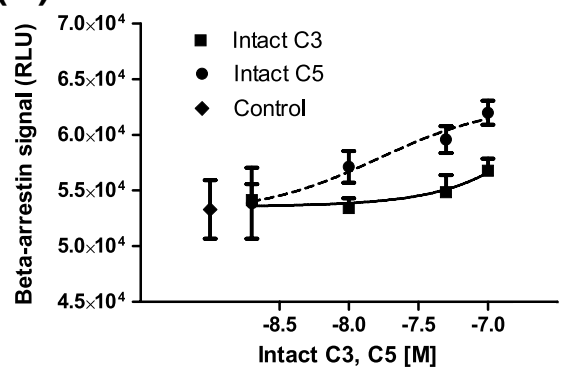

Fig. 4 Islet-derived $\mathrm{C} 3 \mathrm{aR}$ and C5aR1 activating factors. A glucose-dependent increase in beta-arrestin activity of C3aR (a) and C5aR1 (b) was observed in the presence of mouse isletconditioned media, suggesting that $\mathrm{C} 3 \mathrm{aR}$ and $\mathrm{C} 5 \mathrm{aR} 1$-activating factors are released in a glucosedependent manner from mouse islets. $* p<0.05, * * p<0.01$, $* * * p<0.001, n=3-6$

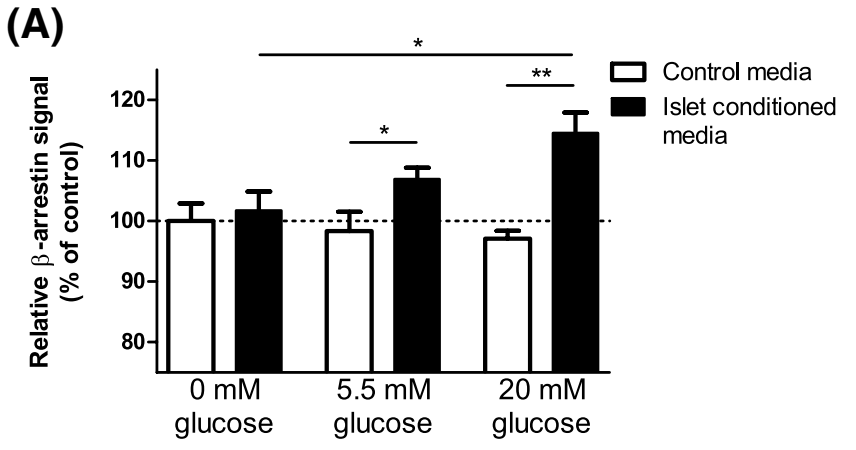

(B)

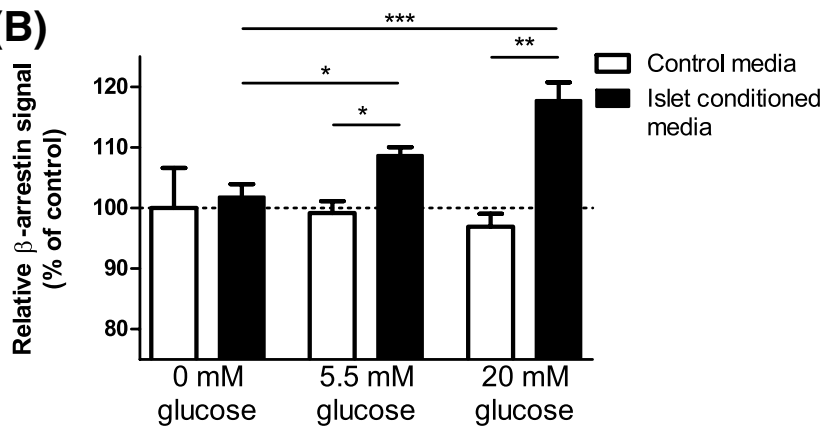

responded to $500 \mu \mathrm{M}$ carbachol with the expected increase in $\left[\mathrm{Ca}^{2+}\right]$ i (Fig. 8).

\section{Effects of C3aR and C5aR1 activation on islet apoptosis}

Mouse and human islet caspase 3/7 activation, induced either by a cocktail of pro-apoptotic cytokines or by the saturated fatty acid palmitate, was significantly inhibited in the presence of C3aR and C5aR1 agonists (Fig. 9a-d). In human islets, the protection against palmitate-induced 
Fig. 5 Effects of complement components on static insulin secretion in islets. Effects of C3aR agonist sc-214644, intact $\mathrm{C} 3$ and $\mathrm{C} 3 \mathrm{aR}$ antagonist SB 290157 (a, c) and C5aR1 agonist 65121-ANA, intact C5 and C5aR1 antagonist PMX 205 (b, d) on glucose-stimulated insulin secretion from mouse $(\mathbf{a}, \mathbf{b})$ and human $(\mathbf{c}, \mathbf{d})$ islets. $\mathrm{C} 3 \mathrm{aR}(1 \mu \mathrm{M}, \mathrm{sc}-214644)$ and C5aR1 (1 $\mu \mathrm{M}, 65121-\mathrm{ANA})$ agonists potentiated glucoseinduced insulin secretion from mouse and human islets, with similar stimulatory effects observed in islets incubated with $100 \mathrm{nM}$ intact $\mathrm{C} 3$ and $\mathrm{C} 5$. Stimulation by intact $\mathrm{C} 3$ and $\mathrm{C} 5$ was blocked by SB 290157 and PMX 205, which also inhibited glucose-induced insulin secretion. $* p<0.05, * * p<0.01$, $* * * p<0.001, n=15$

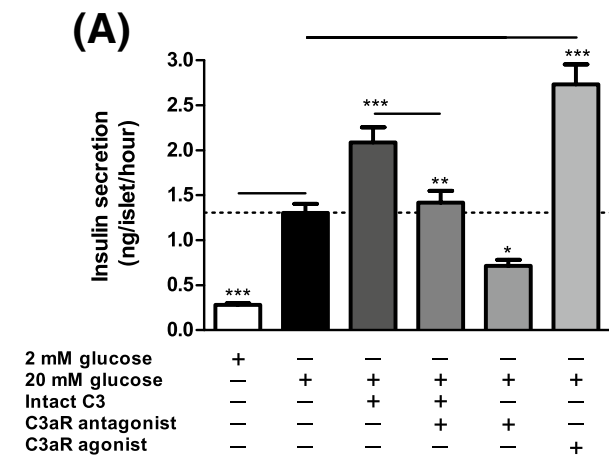

(C)

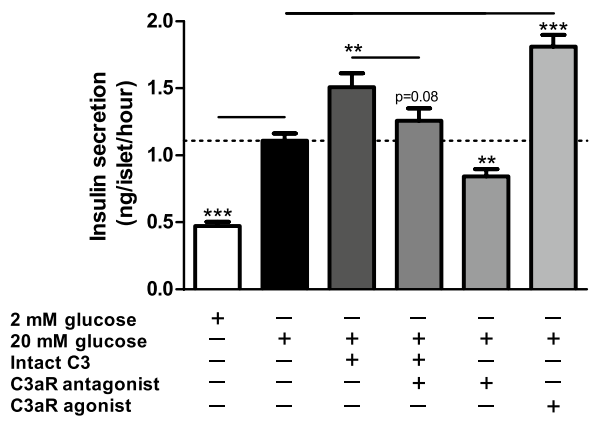

(B)

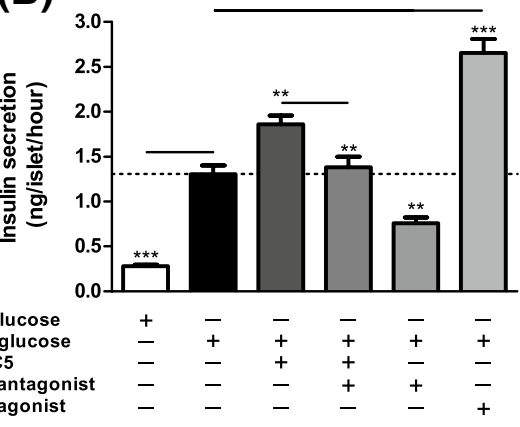

(D)

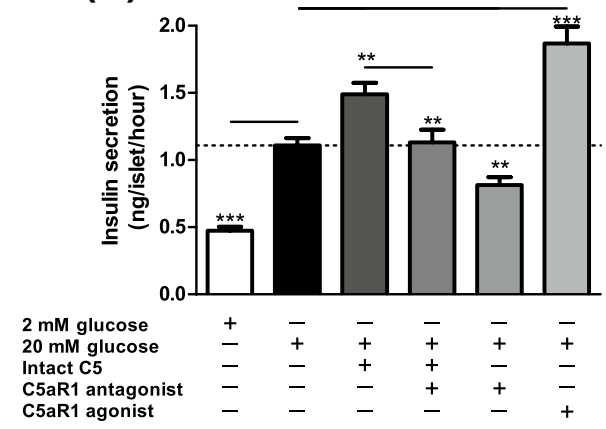

apoptosis by $\mathrm{C} 3 \mathrm{aR}$ and $\mathrm{C} 5 \mathrm{aR} 1$ activation was of a similar magnitude to that of $20 \mathrm{nM}$ Exendin-4, an established antiapoptotic GPCR agonist in islets.

\section{Discussion}

The complement system consists of a tightly regulated network of proteins that play important roles in host defence and inflammation. Intact C3 and C5 proteins and the cleaved $\mathrm{C} 3 \mathrm{a}$ and $\mathrm{C} 5 \mathrm{a}$ peptides are reported to act as mediators of inflammation-induced insulin resistance [9-12], but a beneficial effect of complement factor $\mathrm{D}$, a protease required for the generation of the $\mathrm{C} 3$ convertase, on $\beta$-cell function has been demonstrated [14]. Here, we have demonstrated C3 and C5 mRNA and protein expression by human and mouse islets, and that $\mathrm{C} 3 \mathrm{aR}$ and $\mathrm{C} 5 \mathrm{aR} 1$ activation promotes improvements in islet secretory function and viability.

Our qPCR analysis showed that genes for all complement components studied were present in mouse and human islet preparations. The identification of C3 mRNA in ICR mouse islets, at levels at least tenfold higher than those of C5, is in contrast to an earlier report that $\mathrm{C} 3 \mathrm{mRNA}$ is not expressed by islets isolated from C57 BL/6 mice [14]. The reasons for this discrepancy are not immediately obvious, but may reflect strain-dependent differences in complement protein expression by the pancreas, as we have recently reported for GPCR expression [28]. Our quantification of C3 mRNA in islets from human donors, at levels similar to those identified in ICR mouse islets, also points to its expression by islet cells. However, since mRNA quantifications do not always reflect relative protein expression levels nor importance in a particular tissue [29], we used fluorescence immunohistochemistry to confirm expression of C3 and C5 in mouse and human islets, consistent with a functional role for these complement proteins in islet physiology. We also observed expression of complement proteins by exocrine cells, supporting an earlier report of local production of $\mathrm{C} 3$ in the exocrine pancreas where it was implicated in complementmediated immunological protection [30]. We attempted to identify $\mathrm{C} 3 \mathrm{aR}$ and $\mathrm{C} 5 \mathrm{aR} 1$ expression by mouse and human islets, but we were unable to demonstrate specific staining with commercially available antibodies, consistent with low detection levels obtained by qPCR. Nonetheless, the functional effects of the $\mathrm{C} 3 \mathrm{aR}$ and $\mathrm{C} 5 \mathrm{aR} 1$ activation described in this paper indirectly indicate the presence of these receptors on islet cells.

Traditional assays for GPCRs identify the functional responses elicited by receptor activation and downstream signalling through heterotrimeric $\mathrm{G}$ proteins. Beta-arrestin recruitment, which occurs independently of G-protein coupling, is a powerful screening platform for direct measurement of GPCR activity by detecting interaction of betaarrestin with the activated GPCR [31]. We took advantage of $\mathrm{C} 3 \mathrm{aR}$ and $\mathrm{C} 5 \mathrm{aR} 1$ beta-arrestin assays to demonstrate that islets secreted factors that stimulated C3aR and C5aR1mediated beta-arrestin recruitment in a glucose-dependent manner. To the best of our knowledge, this is the first time 
Fig. 6 Effects of complement components on time-resolved insulin secretion from human islets. Addition of sc-214644 (a) or 65121-ANA (b) to a physiological buffer significantly increased glucose-stimulated insulin secretion from human islets, whereas addition of SB 290157 or PMX 205 in the presence of the corresponding agonist significantly decreased insulin secretion. $* * * p<0.001$, $n=4$

Fig. 7 ATP generation stimulated by complement components in mouse islets. sc-214644, 65121-ANA and intact C3 and C5 significantly stimulated ATP production in mouse islets, whereas SB 290157 and PMX 205 significantly reduced glucose-induced ATP generation. $* p<0.05$, $* * * p<0.001, n=12$

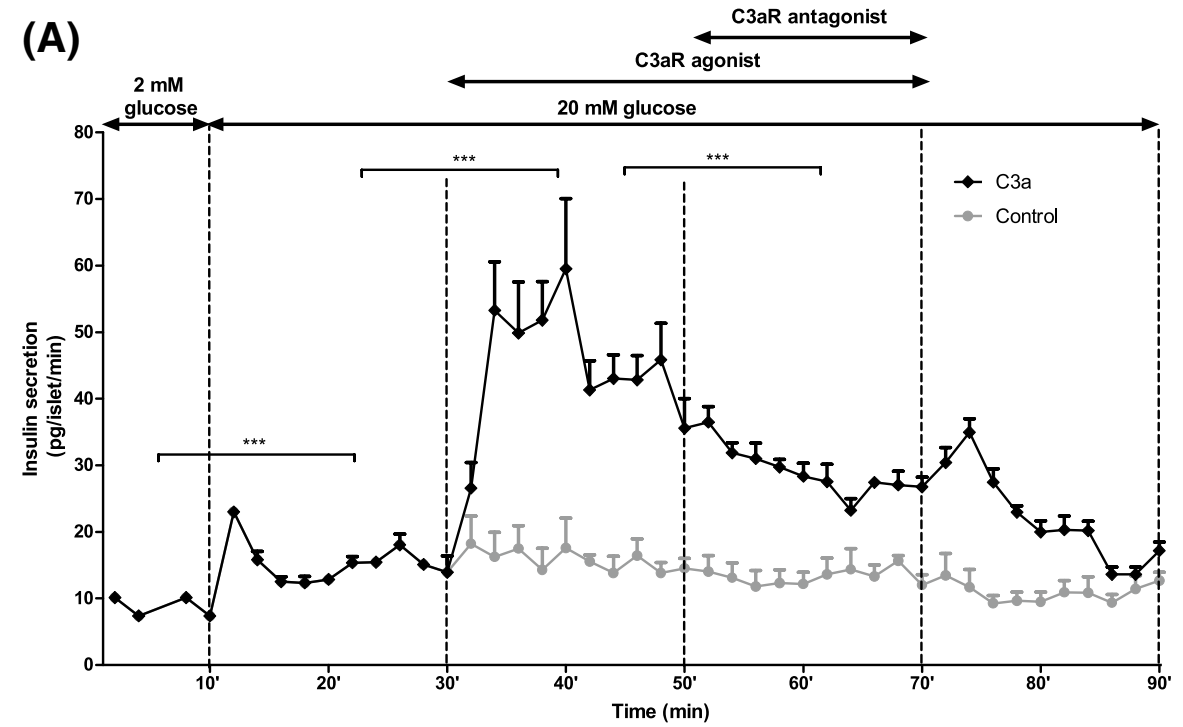

(B)
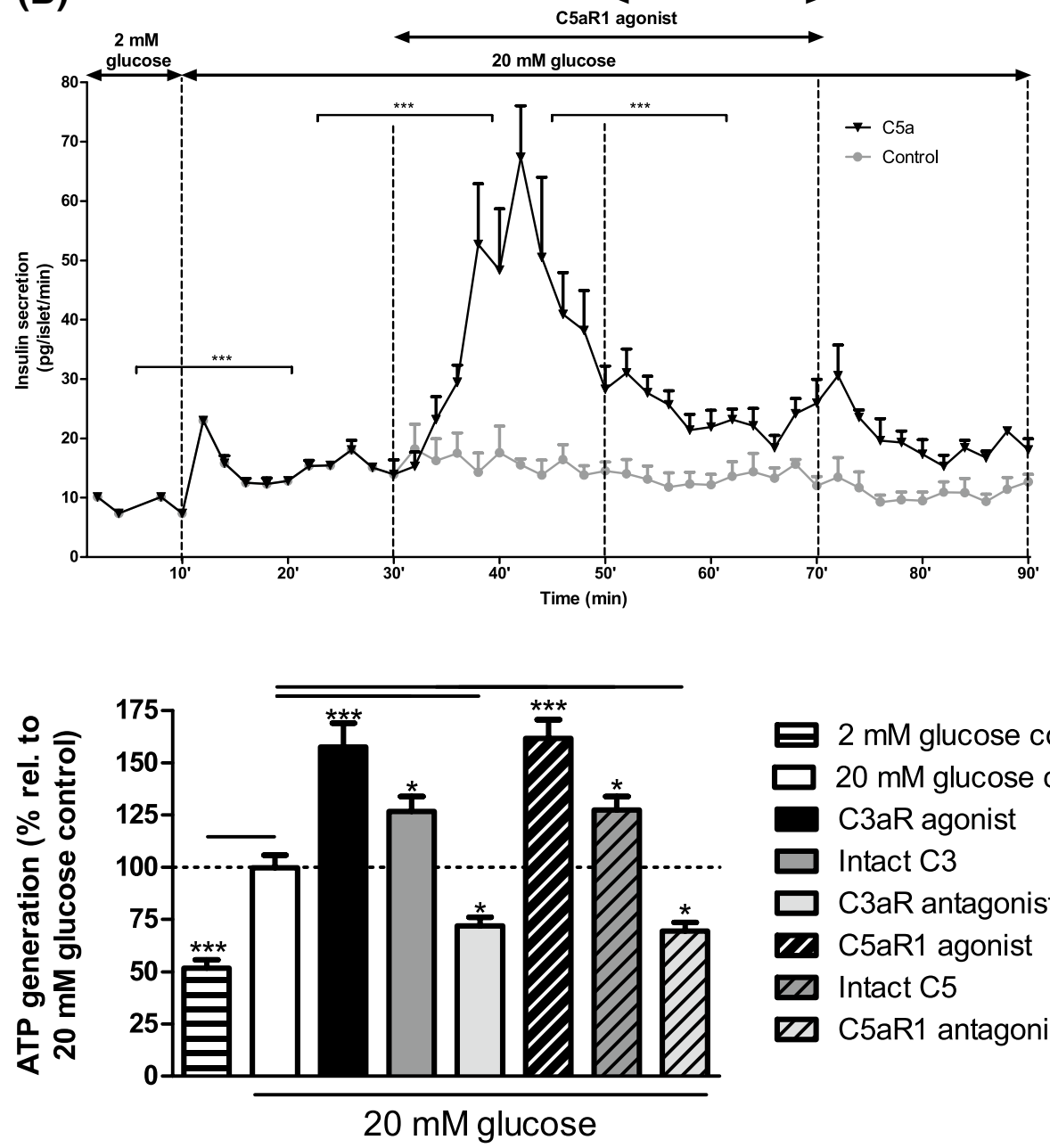

$2 \mathrm{mM}$ glucose control

$\square 20 \mathrm{mM}$ glucose control

C3aR agonist

$\square$ Intact C3

$\square$ C3aR antagonist

2/. C5aR1 agonist

ZIntact C5

Z7 C5aR1 antagonist 


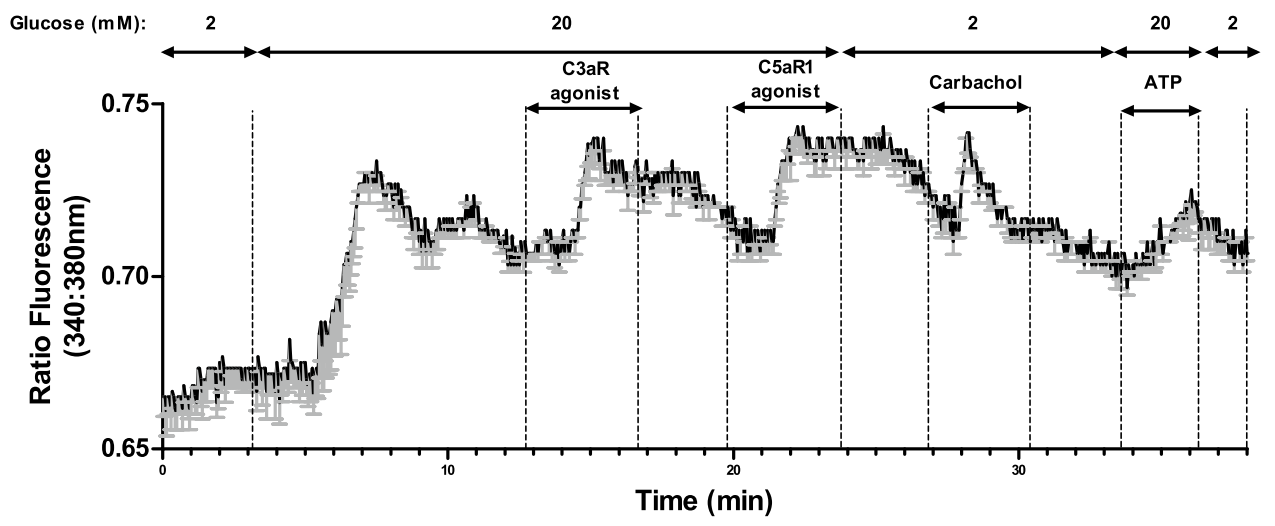

Fig. 8 Stimulatory effects of $\mathrm{C} 3 \mathrm{aR}$ and $\mathrm{C} 5 \mathrm{aR} 1$ agonists on intracellular calcium in mouse islets. C3aR $(1 \mu \mathrm{M}$, sc-214644) and C5aR1 $(1 \mu \mathrm{M}, 65121-\mathrm{ANA})$ agonists reversibly elevated $\left[\mathrm{Ca}^{2+}\right] \mathrm{i}$ in mouse islet cells. $500 \mu \mathrm{M}$ carbachol was used as a positive control. Mean changes in $\left[\mathrm{Ca}^{2+}\right] \mathrm{i}$ levels in six individual cells, expressed as the $340 \mathrm{~nm} / 380 \mathrm{~nm}$ fluorescence ratio, are shown in black and the SEMs for each time point are shown in grey
Fig. 9 Effects of $\mathrm{C} 3 \mathrm{aR}$ and C5aR1 agonists on mouse and human islet apoptosis. Caspase $3 / 7$ activities in mouse $(\mathbf{a}, \mathbf{b})$ and human $(\mathbf{c}, \mathbf{d})$ islets were induced by a cocktail of proapoptotic cytokines $(\mathbf{a}, \mathbf{c})$ or by palmitate (b, d). sc-214644 and 65121-ANA protected against apoptosis in both mouse and human islets. $20 \mathrm{nM}$ Exendin-4 was included as reference treatment for the human islet experiments $(\mathbf{c}, \mathbf{d}) . * * * p<0.001$, $n=6$
(A)

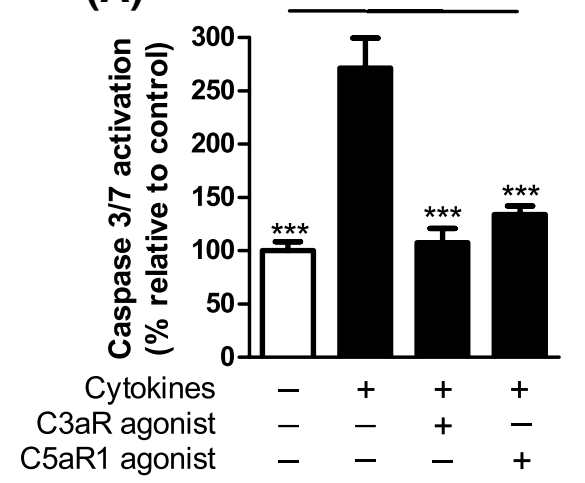

(C)

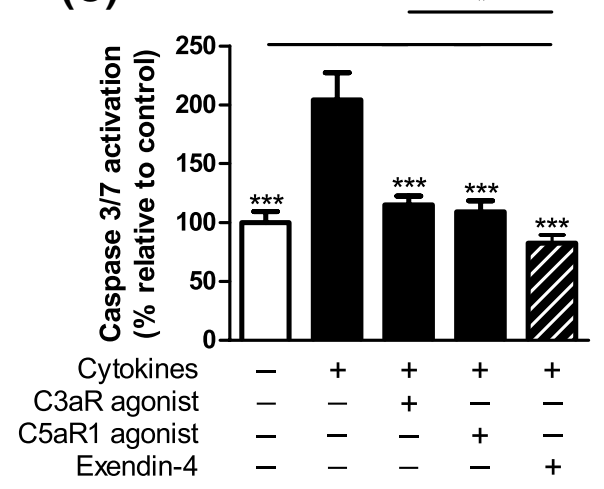

(B)

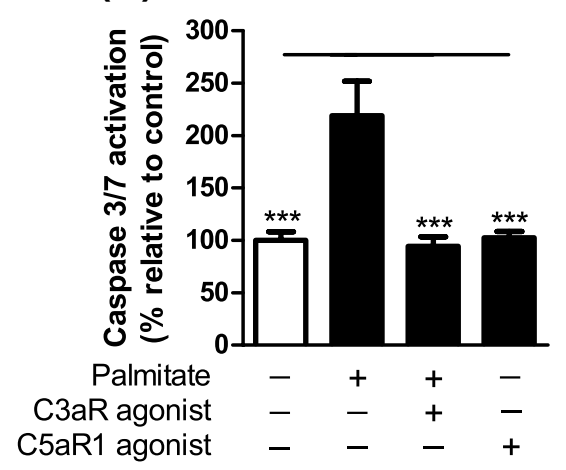

(D)

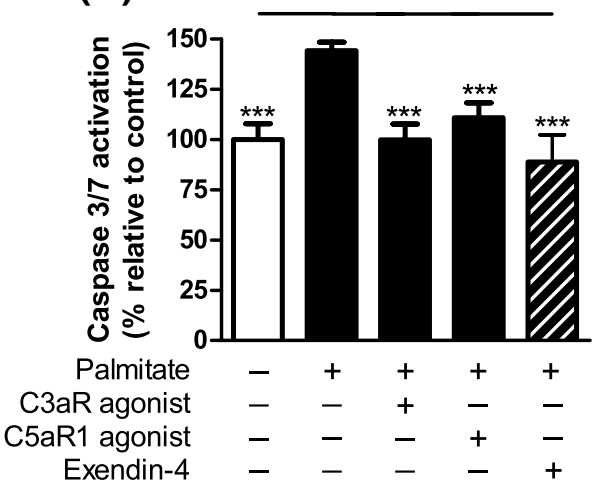

that a cell-based beta-arrestin assay has been used to detect GPCR-activating factors released from islets. The specificity of these assays relies on the use of cell lines in which a small enzyme fragment is fused to the GPCR under investigation and a larger enzyme fragment is fused to beta-arrestin. When the receptor is activated, it binds to beta-arrestin and both enzyme fragments combine, resulting in enzyme activity that is detected by chemiluminescence. The beta-arrestin assays were also used to demonstrate that $\mathrm{C} 3 \mathrm{aR}$ and $\mathrm{C} 5 \mathrm{aR} 1$ agonists caused concentration-dependent activation of the receptors, as expected. Intact C3 and C5 were included in the beta-arrestin assays as negative controls since they are not thought to be agonists of the complement receptors. However, we unexpectedly found that exogenous intact C3 and $\mathrm{C} 5$ proteins stimulated low-level beta-arrestin recruitment, indicative of $\mathrm{C} 3 \mathrm{aR}$ and $\mathrm{C} 5 \mathrm{aR} 1$ activation, respectively. 
These data suggest that there was local production of the active $\mathrm{C} 3 \mathrm{a}$ and $\mathrm{C} 5 \mathrm{a}$ peptides in these experiments, either through expression of the corresponding convertases by the reporter U2OS and CHO-K1 cells or by proteases in the serum-supplemented medium, in accordance with published studies of spontaneous $\mathrm{C} 3$ activation in plasma [32, 33]. It cannot, however, be ruled out that intact $\mathrm{C} 3$ and $\mathrm{C} 5$ can act as low-affinity, direct activators of C3aR and C5aR1.

Plasma levels of $\mathrm{C} 3$ are positively associated with insulin secretion in non-diabetic human subjects, which may suggest that C3 is a contributor to insulin release [34]. Stimulatory effects on insulin secretion from mouse islets have been reported for acylation stimulating protein, a desArg derivative of $\mathrm{C} 3 \mathrm{a}$ [35] and C3a itself, effects mediated by activation of islet $\mathrm{C} 3 \mathrm{aR}$ [14]. Building on these earlier studies we have now observed that $\mathrm{C} 3 \mathrm{aR}$ and $\mathrm{C} 5 \mathrm{aR} 1$ agonists potentiated glucose-stimulated insulin secretion from both human and mouse islets, consistent with $\mathrm{C} 3 \mathrm{aR}$ and C5aR1 being key positive regulators of insulin secretion. Similar stimulatory effects were observed with intact C3 and C5, suggesting that they are cleaved to the active peptides by their convertases, or that the proteins may themselves act as low-affinity direct activators of their corresponding receptors. Intact $\mathrm{C} 3$ and $\mathrm{C} 5$ were used for these experiments at $100 \mathrm{nM}$, which is lower than circulating concentrations of these complement components [36]. However, we have shown here that there is local production of these proteins by islets and it is possible that autocrine or paracrine signalling within islets occurs at lower concentrations than are reached during inflammation-mediated elevations in circulating intact C3 and C5. Antagonists of C3aR (SB 290157) and C5aR1 (PMX 205 and W 54011) induced concentrationdependent inhibition of glucose-stimulated insulin secretion, even in the absence of exogenously added C3aR and C5aR1 agonists. This in vitro inhibition of insulin secretion suggests that the endogenous islet-derived complement $\mathrm{C} 3 / \mathrm{a}$ and C5/a peptides normally act in an auto/paracrine manner when released from islets to promote insulin release. These results are also in agreement with an earlier study in which antagonism of C3aR in $d b / d b$ mice with SB 290157 inhibited adipsin-mediated improvements in glucose tolerance and insulin secretion [14].

It is well established that glucose metabolism and ATP synthesis in $\beta$-cells is essential for $\mathrm{Ca}^{2+}$ influx and insulin granule exocytosis [37]. $\mathrm{C} 3 \mathrm{aR}$ and $\mathrm{C} 5 \mathrm{aR} 1$ are pertussis toxin-sensitive GPCRs [38, 39], suggesting signalling through Gi that does not fit with their stimulatory effects on insulin release. However, it has been reported that $\mathrm{C} 3 \mathrm{aR}$ activation can elevate $\left[\mathrm{Ca}^{2+}\right] \mathrm{i}[14]$, perhaps via Gq coupling. We found that $\mathrm{C} 3 \mathrm{aR}$ and $\mathrm{C} 5 \mathrm{aR} 1$ agonists significantly increased $\left[\mathrm{Ca}^{2+}\right] \mathrm{i}$ in mouse islets and they also led to significant elevations in ATP generation, as did intact $\mathrm{C} 3$ or $\mathrm{C} 5$. These observations suggest that islet $\mathrm{C} 3 \mathrm{aR}$ - and $\mathrm{C} 5 \mathrm{aR} 1$-mediated elevations in $\left[\mathrm{Ca}^{2+}\right]$ i may lead to increased mitochondrial $\left[\mathrm{Ca}^{2+}\right]$ [40], promoting Krebs cycle activity and leading to enhanced ATP content. The C3aR and C5aR1 antagonists significantly inhibited glucose-stimulated ATP production, which may have been responsible, at least in part, for their inhibitory effects of glucose-stimulated insulin secretion.

A major feature of T2D is the progressive loss of $\beta$-cell mass, reflecting a shift from islet quiescence/proliferation to $\beta$-cell apoptosis [1]. An anti-apoptotic effect of a C5aR1 agonist in neurons has been reported [41], an unexpected function for an anaphylatoxin. Further evidence of a protective role for complement peptides is provided by a recent study in which C3a and C5a peptides reduced apoptosis of myeloid and lymphoid cells [42]. In the current study, activation of mouse and human islet C3aR and C5aR1 led to a robust reduction in apoptosis that had been induced by a cytokine cocktail or the saturated fatty acid palmitate. This apparent paradoxical effect of complement cascade components may be a protective mechanism to maintain $\beta$-cell mass in conditions such as obesity, which normally exerts increased stress on the $\beta$-cell population. These findings also support previous proposals of a beneficial role of complement proteins on tissue remodelling [43].

In summary, our data reveal that $\mathrm{C} 3$ and $\mathrm{C} 5$ complement proteins and their receptors are expressed by human and mouse islets, and that islets secrete complement receptor activating ligands in a glucose-dependent manner. Activation of islet $\mathrm{C} 3 \mathrm{aR}$ and $\mathrm{C} 5 \mathrm{aR} 1$ results in increased intracellular calcium and ATP levels, potentiation of glucose-induced insulin secretion and protection against apoptosis. These observations demonstrate a functional link between activation of components of the innate immune and improved human and mouse $\beta$-cell function, suggesting that complement peptides exert direct stimulatory effects at islet $\beta$-cells that could compensate for their induction of peripheral insulin resistance.

Acknowledgements The study was designed by SA, PA and SJP. Data were collected and analysed by PA, SA, IRM, AP, RH and BL. $\mathrm{GCH}$ and $\mathrm{MZ}$ provided human islets of Langerhans. The article was drafted by PA, SA and SJP. All authors revised the article critically for intellectual content and gave their approval of this version to be published. PA, SA and SJP take responsibility for the contents of the article. We are grateful to the relatives of organ donors for human pancreases for research. This study was supported by grants from the EFSD/Boehringer-Ingelheim Research Programme and a Diabetes UK RD Lawrence Fellowship to SA (11/0004172). All authors declare that they have no competing interests.

Open Access This article is distributed under the terms of the Creative Commons Attribution 4.0 International License (http://creativecommons.org/licenses/by/4.0/), which permits unrestricted use, distribution, and reproduction in any medium, provided you give appropriate credit to the original author(s) and the source, provide a link to the Creative Commons license, and indicate if changes were made. 


\section{References}

1. Ribbing J, Hamren B, Svensson MK, Karlsson MO (2010) A model for glucose, insulin, and beta-cell dynamics in subjects with insulin resistance and patients with type 2 diabetes. J Clin Pharmacol 50:861-872

2. Sarma JV, Ward PA (2011) The complement system. Cell Tissue Res 343:227-235

3. Hollmann TJ, Haviland DL, Kildsgaard J, Watts K, Wetsel RA (1998) Cloning, expression, sequence determination, and chromosome localization of the mouse complement $\mathrm{C} 3 \mathrm{a}$ anaphylatoxin receptor gene. Mol Immunol 35:137-148

4. Gerard NP, Bao L, Xiao-Ping H, Eddy RL Jr, Shows TB, Gerard C (1993) Human chemotaxis receptor genes cluster at 19q13.3-13.4. Characterization of the human $\mathrm{C} 5$ a receptor gene. Biochemistry 32:1243-1250

5. Okinaga S, Slattery D, Humbles A et al (2003) C5L2, a nonsignaling C5A binding protein. Biochemistry 42:9406-9415

6. Engstrom G, Hedblad B, Eriksson KF, Janzon L, Lindgarde F (2005) Complement C3 is a risk factor for the development of diabetes: a population-based cohort study. Diabetes 54:570-575

7. McMillan DE (1980) Elevation of complement components in diabetes mellitus. Diabetes Metab 6:265-270

8. Morimoto Y, Taniguchi H, Yamashiro Y, Ejiri K, Baba S, Arimoto Y (1988) Complements in diabetes mellitus: activation of complement system evidenced by C3d elevation in IDDM. Diabetes Res Clin Pract 5:309-312

9. Wlazlo N, van Greevenbroek MM, Ferreira I et al (2014) Complement factor 3 is associated with insulin resistance and with incident type 2 diabetes over a 7-year follow-up period: the CODAM Study. Diabetes Care 37:1900-1909

10. Mamane Y, Chung Chan C, Lavallee G et al (2009) The C3a anaphylatoxin receptor is a key mediator of insulin resistance and functions by modulating adipose tissue macrophage infiltration and activation. Diabetes 58:2006-2017

11. Hasty TKDAGEKA-BWRBMJHBTPOPMAH (2015) Complement factor 5 deficiency leads to defective insulin receptor processing and severe systemic insulin resistance. http://www. endocrine-abstracts.org/ea/0037/ea00370C4.2.htm

12. Phieler J, Chung KJ, Chatzigeorgiou A et al (2013) The complement anaphylatoxin $\mathrm{C} 5$ a receptor contributes to obese adipose tissue inflammation and insulin resistance. J Immunol 191:4367-4374

13. Lim J, Iyer A, Suen JY et al (2013) C5aR and C3aR antagonists each inhibit diet-induced obesity, metabolic dysfunction, and adipocyte and macrophage signaling. FASEB J 27:822-831

14. Lo JC, Ljubicic S, Leibiger B et al (2014) Adipsin is an adipokine that improves beta cell function in diabetes. Cell 158:41-53

15. Liu B, Hassan Z, Amisten S et al (2013) The novel chemokine receptor, G-protein-coupled receptor 75, is expressed by islets and is coupled to stimulation of insulin secretion and improved glucose homeostasis. Diabetologia 56:2467-2476

16. Huang GC, Zhao M, Jones P et al (2004) The development of new density gradient media for purifying human islets and islet-quality assessments. Transplantation 77:143-145

17. Amisten S, Braun OO, Bengtsson A, Erlinge D (2008) Gene expression profiling for the identification of G-protein coupled receptors in human platelets. Thromb Res 122:47-57

18. Amisten S (2016) Quantification of the mRNA expression of $G$ protein-coupled receptors in human adipose tissue. Methods Cell Biol 132:73-105

19. Amisten S (2012) A rapid and efficient platelet purification protocol for platelet gene expression studies. Methods Mol Biol 788:155-172
20. Pfaffl MW (2001) A new mathematical model for relative quantification in real-time RT-PCR. Nucleic Acids Res 29:e45

21. Gey GOGM (1936) The maintenance of human normal cells and tumor cells in continuous culture: I. Preliminary report: cultivation of mesoblastic tumors and normal tissue and notes on methods of cultivation. Am J Cancer 27:45-76

22. Jones PM, Salmon DM, Howell SL (1988) Protein phosphorylation in electrically permeabilized islets of Langerhans. Effects of $\mathrm{Ca}^{2+}$, cyclic AMP, a phorbol ester and noradrenaline. Biochem J 254:397-403

23. Jones PM, Persaud SJ, Howell SL (1989) Time-course of $\mathrm{Ca}^{2+}$-induced insulin secretion from perifused, electrically permeabilised islets of Langerhans: effects of cAMP and a phorbol ester. Biochem Biophys Res Commun 162:998-1003

24. Liu B, Asare-Anane H, Al-Romaiyan A et al (2009) Characterisation of the insulinotropic activity of an aqueous extract of Gymnema sylvestre in mouse beta-cells and human islets of Langerhans. Cell Physiol Biochem 23:125-132

25. Holers VM (2014) Complement and its receptors: new insights into human disease. Annu Rev Immunol 32:433-459

26. Norgauer J, Dobos G, Kownatzki E et al (1993) Complement fragment C3a stimulates $\mathrm{Ca}^{2+}$ influx in neutrophils via a pertussistoxin-sensitive G protein. Eur J Biochem 217:289-294

27. Karsten CM, Laumonnier Y, Kohl J (2014) Functional analysis of $\mathrm{C} 5 \mathrm{a}$ effector responses in vitro and in vivo. Methods Mol Biol 1100:291-304

28. Amisten S, Atanes P, Hawkes R et al (2017) A comparative analysis of human and mouse islet G-protein coupled receptor expression. Sci Rep 7:46600

29. de Sousa Abreu R, Penalva LO, Marcotte EM, Vogel C (2009) Global signatures of protein and mRNA expression levels. Mol BioSyst 5:1512-1526

30. Andoh A, Fujiyama Y, Sumiyoshi K, Bamba T (1996) Local secretion of complement $\mathrm{C} 3$ in the exocrine pancreas: ductal epithelial cells as a possible biosynthetic site. Gastroenterology 110:1919-1925

31. Kang DS, Tian X, Benovic JL (2014) Role of beta-arrestins and arrestin domain-containing proteins in $\mathrm{G}$ protein-coupled receptor trafficking. Curr Opin Cell Biol 27:63-71

32. Manderson AP, Pickering MC, Botto M, Walport MJ, Parish CR (2001) Continual low-level activation of the classical complement pathway. J Exp Med 194:747-756

33. Amara U, Flierl MA, Rittirsch D et al (2010) Molecular intercommunication between the complement and coagulation systems. J Immunol 185:5628-5636

34. Fiorentino TV, Hribal ML, Andreozzi F et al (2015) Plasma complement C3 levels are associated with insulin secretion independently of adiposity measures in non-diabetic individuals. Nutr Metab Cardiovasc Dis 25:510-517

35. Ahren B, Havel PJ, Pacini G, Cianflone K (2003) Acylation stimulating protein stimulates insulin secretion. Int J Obes Relat Metab Disord 27:1037-1043

36. Sen DK, Sarin GS, Hiranandani M, Baveja UK (1985) Serum complement components in patients with trachoma. Br J Ophthalmol 69:707-710

37. Hou JC, Min L, Pessin JE (2009) Insulin granule biogenesis, trafficking and exocytosis. Vitam Horm 80:473-506

38. Hannedouche S, Beck V, Leighton-Davies J et al (2013) Identification of the C3a receptor (C3AR1) as the target of the VGF-derived peptide TLQP-21 in rodent cells. J Biol Chem 288:27434-27443

39. Seow V, Lim J, Iyer A et al (2013) Inflammatory responses induced by lipopolysaccharide are amplified in primary human monocytes but suppressed in macrophages by complement protein C5a. J Immunol 191:4308-4316 
40. Rizzuto R, Marchi S, Bonora M et al (2009) $\mathrm{Ca}(2+)$ transfer from the ER to mitochondria: when, how and why. Biochem Biophys Acta 1787:1342-1351

41. Benard M, Gonzalez BJ, Schouft MT et al (2004) Characterization of $\mathrm{C} 3 \mathrm{a}$ and $\mathrm{C} 5 \mathrm{a}$ receptors in rat cerebellar granule neurons during maturation. Neuroprotective effect of C5a against apoptotic cell death. J Biol Chem 279:43487-43496
42. Mueller-Ortiz SL, Calame DG, Shenoi N, Li YD, Wetsel RA (2017) The complement anaphylatoxins C5a and C3a suppress IFN-beta production in response to Listeria monocytogenes by inhibition of the cyclic dinucleotide-activated cytosolic surveillance pathway. J Immunol 198:3237-3244

43. Mastellos D, Lambris JD (2002) Complement: more than a 'guard' against invading pathogens? Trends Immunol 23:485-491 